\title{
MOTIVASI BERPRESTASI ATLET MUDA DALAM MENGHADAPI \\ PEKAN OLAHRAGA NASIONAL TAHUN 2012 DITINJAU DARI KEPERCAYAAN DIRI
}

\author{
Syarifah Farradinna \\ Fakultas Psikologi Universitas Islam Riau Pekanbaru \\ Email: deen_rc@yahoo.co.uk
}

\begin{abstract}
The aim of this study is to analyze the correlation between self confidence and achievement motivation, and also to find out the impact of self confidence on athletes' achievement motivation while facing the $18^{\text {th }}$ PON. Subjects in this research are 99 young athletes from Riau, male and female, that are going to face the $18^{\text {th }}$ PON in 2012. This study is modify Moore's SelfConfident Scale and Falah Yunus' Achivement Motivation Scale. This study use Pearson's Product Moment Correlation to examine whether there is a correlation between self confidence and athletes' achievement motivation, while facing the $18^{\text {th }}$ PON in 2012. This study also use the Regression Analysis to find out the impact of self confidence on athletes' achievement motivation while facing the $18^{\text {th }} P O N$. Data analysis shows $r=0.371$ and $p=0.000(p<0.001)$ which means that there is a very significant positive correlation between self confidence and achievement motivation. From the result of the study, we can conclude that self confidence has impact on achievement motivation.
\end{abstract}

Keywords: self confidence, achievement motivation

Keterlibatan atlet muda dalam kompetisi bertaraf nasional ini tidak terlepas dari kemampuan psikologis yang sehat pada atlet muda itu sendiri. Kesuksesan dalam kompetisi merupakan hasil dari perencanaan, kerja kerjas dan komitmen, serta latihan yang berdisiplin tinggi. Aktivitas fisik yang dirancang dengan baik, program latihan yang berlangsung dalam jangka waktu yang panjang dapat menampilkan prestasi yang cemerlang. Hal ini selaras dengan pendapat Siddik (http://www.koni.or.id) bahwa dalam melatih atlet-atlet muda harus dengan seksama memperhatikan dan memahami prinsip-prinsip latihan yang dikaji dalam ilmu faal, teori pertumbuhan dan perkembangan anak, psikologi, nutrisi dan pedagogik agar prestasi puncak dapat dicapai sesuai dengan rencana. Pasiak (2004) mengungkapkan dalam salah satu metode ALISSA, yaitu latihan fisik motorik dapat meningkatkan olah otak individu yang memfungsikan kecerdasan emosi yang dimilikinya. Menurutnya, antara otak dan otot memiliki kedekatan, jika otot terlatih dengan baik, sirkulasi darah dalam tubuh juga berlangsung baik. Artinya, oksigen dan gula darah akan beredar secara baik ke dalam otak.

Penampilan yang ditunjukkan oleh para atlet muda dalam kompetisi ini sangat dipengaruhi oleh aspek psikologis yang baik pada setiap individu. Pengembangan penampilan individu dalam aspek psikologisnya seperti perasaan percaya diri (self confidence), kegembiraan, harga diri, pengalaman merasakan pecapaian prestasi, pengakuan dari teman sebaya. Sebaliknya, jika individu mendapatkan pengalaman yang negatif dalam berolahraga, maka aspek psikologi pun dapat berkembang secara negatif. Penilaian negatif, frustrasi, agresi dan tidak percaya diri akan muncul.

Ancok dan Suroso (2008) mengungkapkan bahwa setiap pribadi diharapkan memiliki sejenis virus yang berisi sifat rajin, suka bekerja keras, kalau 
mengerjakan sesuatu ingin melakukannya dengan sebaik-baiknya, serta selalu ingin berbuat yang lebih baik dibanding yang pernah diperbuat di masa-masa sebelumnya. Dengan kata lain atlet diharapkan mempunyai motif berprestasi (need for achievement) yang tinggi.

McClelland (Uy un, 1998 ) menambahkan bahwa individu yang mempunyai motivasi berprestasi tinggi akan mempunyai rasa tanggung jawab dan rasa percaya diri yang tinggi, lebih ulet, lebih giat dalam melaksanakan suatu tugas, mempunyai keinginan untuk menyelesaikan tugasnya dengan baik. Oleh karena itu prestasi yang dicapai biasanya akan lebih baik daripada individu yang rendah motif berprestasnya. Individu akan lebih tahan terhadap tekanan-tekanan sosial, lebih suka memilih teman sekedar teman akrab, dalam bertindak selalu mempertimbangkan resiko tingkat sedang.

Motif berprestasi atlet dipengaruhi faktor-faktor internal dan eksternal. Kepercayaan diri individu dapat berasal dari berbagai media, khususnya perhatian yang diberikan oleh pelatih dan tim nya dalam meningkatkan kemampuan dalam setiap penampilan anak. Sebaliknya, ketika pelatih tersebut tidak memberikan dukungan sosial tendensi seorang individu untuk mengambil peran dan kontribusi nya dalam pertandingan. David dan Palladino (Thomas \& Kring, 1996) menjelaskan rendahnya kepercayaan diri individu menyebabkan rendahnya motivasi, menunjukkan rendahnya persepsi terhadap kemampuan dirinya dan tidak dapat mengembangkan diri dari metode pelatihan yang diberikan oleh pelatihnya.

Trenz (http://www.koni.or.id) menambahkan bahwa dukungan terbesar para atlet adalah pelatih yang memberikan lingkungan nyaman dan memeberikan motivasi yang besar terhadap atlet dalam hal proses belajar dan termotivasi mencapai suatu prestasi. Setiap atlet muda harus memiliki suatu keinginan dan mencapainya, memiliki keinginan untuk menyelesaikan dengan keberhasilan setiap tanggung jawab yang mereka miliki, yaitu sebagai atlet muda yang mewakili dan membawa nama bagi daerah nya. Dengan demikian, tekanan dan tanggung jawab atlet muda Riau lebih berat dari kompetisi biasanya, untuk itu dengan kepercayaan diri terhadap diri dapat menjadi suatu hal terpenting dalam memotivasi atlet mencapai prestasi yang diharapkan oleh masyarakat Riau. Adapun tujuan penelitian ini untuk menganalisis hubungan antara Kepercayaan Diri dengan Motivasi Berprestasi, sekaligus untuk mengetahui sejauh mana Peran Kepercayaan Diri terhadap Motivasi Berprestasi atlet dalam menghadapi PON Ke-18 tahun 2012. Secara teoritis, penelitian ini dapat digunakan untuk mengembangkan teroi psikologi sosial, psikologi olah raga, terutama mengenai kepercayaan diri dan motivasi berprestasi. Secara praktis, hasil penelitian ini dapat digunakan untuk mengembangkan potensi atlet dalam menghadapi kompetisi nasional maupun international sehubungan dengan kepercayaan diri dan motivasi berprestasinya.

Berdasarkan penjelasan di atas dapat dirumuskan hipotesis bagi penelitian ini adalah ada hubungan positif antara Kepercayaan Diri dengan Motivasi Berprestasi pada Atlet Muda dalam Menghadapi PON Ke-18 Tahun 2012.

\section{METODE PENELITIAN}

\section{Subjek Penelitian}

Subjek penelitian adalah sumber utama data penelitian, yaitu yang memiliki data mengenai variabel-variabel yang diteliti. Apabila subjek penelitiannya terbatas dan masih dalam jangkauan sumber daya, maka dapat dilakukan studi populasi yaitu mempelajari seluruh subjek secara langsung (Azwar, 1998).

Pada penelitian ini, teknik sampling yang digunakan dalam menentukan subjek penelitian adalah dengan menggunakan teknik quota sampling. Alasan dengan menggunakan teknik ini adalah karena sulitnya menemukan atlet-atlet yang telah direkomendasikan sebagai atlet yang akan mengikuti Pekan Olahraga Nasional ke-18 tahun 2012. 


\section{Metode dan Alat Pengumpulan Data}

Pengumpulan data dilakukan dengan menggunakan skala. Skala digunakan untuk mengungkapkan data yang berupa konstrak psikologis, yaitu skala kepercayaan diri dan skala motivasi berprestasi. Hasil try out alat ukur menunjukkan bahwa skala kepercayaan diri memiliki koefisen alpha 0.911. Hasil try out alat ukur juga menunjukkan bahwa skala motif berprestasi memiliki koefisien alpha 0.773 .

Penggunaan skala model Likert telah dimodifikasi dengan menghilangkan jawaban tengah. Dengan demikian, pada setiap skala yang disusun hanya terdapat empat alternatif jawaban yang ditawarkan.

\section{Metode Analisis Data}

Analisis data penelitian yang sudah diperoleh dimaksudkan sebagai suatu cara mengorganisasikan data sedemikian rupa sehingga dapat dibaca dan dapat ditafsirkan. Analisis statistik yang digunakan untuk menguji hipotesis pada penelitian ini adalah korelasi product moment dari Karl Perason dan analisis regresi untuk mencari seberapa besar sumbangan variabel bebas terhadap variabel tergantung.

\section{HASIL PENELITIAN \\ Deskripsi Subjek}

Hasil penelitian menunjukkan bahwa terdapat 99 subjek penelitian yang dilakukan dengan quota sampling. Mereka adalah atlet Propinsi Riau yang akan mengikuti Pekan Olahraga Nasional 2012.

Quota Sampling adalah salah satu teknik dengan melakukan pengambilan sampel kepada sejumlah kuota sampel dari populasi dan menghentikan pengambilan setelah quota terpenuhi.

Tabel1. Karakteristik Jumlah Subjek

\begin{tabular}{cc}
\hline Cabang Olahraga & Total \\
\hline Atletik & 25 \\
Tinju & 14 \\
Pencak Silat & 20 \\
Taekwondo & 20 \\
Panahan & 20 \\
\hline Total & 99 orang \\
\hline
\end{tabular}

Berdasarkan hasil penelitian deskripsi statistik diperoleh rentangan skor bagi skala kepercayaan diri Atlet berkisar antara 69 sampai 134 berdasarkan data empiris. Dari skor ini pula diperoleh rerata/mean 111,2323 dengan Standard Deviasi 12,20641. Sedangkan skala Motivasi Berprestasi berkisar antara 22 sampai 52 berdasarkan data empiris. Dari skor ini pula diperoleh rerata 43,6667 dengan Standard Deviasi 5,48281 .

\section{Skala Motivasi Berprestasi}

Berdasarkan skor yang ditetapkan dan jumlah item skala, maka secara hipotetik variabel ini memiliki jarak sebaran 32, sedangkan standar deviasinya sebesar 10 dengan mean sebaran sebesar 36. kategori ini dapat dilihat pada tabel 1 berikut ini:

Tabel 2.Kriteria Penilaian Skala Motivasi Berprestasi

\begin{tabular}{cc}
\hline Kategorisasi & Skor \\
\hline Sangat Tinggi & $\mathrm{X}=51.890$ \\
Tinggi & $46.40<\mathrm{X}=$ \\
& 51.890 \\
Sedang & $40.925<\mathrm{X}=$ \\
& 46.408 \\
Rendah & $35.442<\mathrm{X}=$ \\
Sangat Rendah & 40.925 \\
& $\mathrm{X}=35.442$ \\
\hline
\end{tabular}

Berdasarkan tabel diatas di simpulkan bahwa subjek dalam peneltiian ini memiliki tingkat motivasi berprestasi yang rendah, dengan menunjukkan nilai mean sebesar 36 .

\section{Skala Kepercayaan Diri}

Berdasarkan skor yang ditetapkan dan jumlah item skala, maka secara hipotetik variabel ini memiliki jarak sebaran 93, sedangkan standar deviasinya sebesar 20.5 dengan mean sebaran sebesar 637.5. kategori ini dapat dilihat pada tabel 2 berikut ini:

Tabel 2. Kriteria Penilaian Skala Kepercayaan Diri

\begin{tabular}{cl}
\hline Kategorisasi & \multicolumn{1}{c}{ Skor } \\
\hline Sangat Tinggi & $\mathrm{X}=129.54$ \\
Tinggi & $117.335<\mathrm{X}=129.54$ \\
Sedang & $105.1290<\mathrm{X}=117.335$ \\
Rendah & $92.922<\mathrm{X}=105.129$ \\
Sangat & $\mathrm{X}=92.922$ \\
Rendah & \\
\hline
\end{tabular}


Berdasarkan tabel di atas disimpulkan bahwa subjek dalam peneltian ini memiliki tingkat Kepercayaan Diri yang Sangat Rendah, dengan menunjukkan nilai mean sebesar 87.5.

\section{Uji Normalitas}

Uji asumsi pada penelitian ini terdiri dari uji normalitas dan uji linearitas, yang merupakan syarat untuk dilakukan pengujian korelasi.

Berdasarkan hasil yang diperoleh bahwa perhitungan Kolmogorov - Smirnov Z (K-Sz) terhadap variabel motivasi berprestasi menghasilkan $\mathrm{K}-\mathrm{Sz}$ sebesar 0.879 dengan $p=0.422(p>0.05)$, sedangkan pada Variabel Kepercayaan Diri menunjukkan perolehan K-Sz sebesar 1.378 dengan $\mathrm{p}=0.045(\mathrm{p}>0.01)$ sehingga hasil ini menunjukkan bahwa kecua variabel tersebut memiliki distribusi normal.

\section{Uji Linearitas}

Uji linearitas dilakukan pada masingmasing variabel, perhitungan linearitas penelitian ini menunjukkan hasil perhitungan Anova Regression untuk Motivasi berprestasi dan Kepercayaan Diri menghasilkan nilai $\mathrm{F}=2.921$ dengan nilai $\mathrm{p}=$ $0.00(\mathrm{p}<0.01)$ dengan demikian hasilnya signifikan.

\section{Uji Hipotesis}

Uji Hipotesis dalam penelitian ini adalah dengan menggunakan teknik analisis korelasi product moment. Yang menunjukkan ada korelasi positif antara motivasi berprestasi dengan kepercayaan diri yang bernilai sebesar $\mathrm{r}=0.371, \mathrm{p}=0.000$ $(p<0.01)$ yang berarti Sangat signifikan. Dengan demikian hipotesis dari penelitian ini dapat diterima yaitu terdapat hubungan positif antara Motivasi Berprestasi dengan Kepercayaan Diri Pada Atlet.

\section{Uji Sumbangan Efektif}

Hasil dari uji sumbangan efektif pada penelitian ini menunjukkan nilai $\mathrm{R}=0.371$ dengan R2=0.137, yang berarti Kepercayaan Diri memberikan sumbangan sebesar 13.7\% terhadap motivasi berprestasi pada Atlet. Sedangkan $86.5 \%$ lainnya berasal dari faktor lain.

\section{PEMBAHASAN}

Hasil penelitian menunjukkan bahwa kepercayaan diri berpengaruh terhadap motif berprestasipara atlet. Kepercayaan diri merupakan aspek kepribadian manusia yang berfungsi penting untuk mengaktualisasikan potensi yang dimilikinya. Tanpa kepercayaan diri, banyak masalah akan timbul pada manusia. Kepercayaan diri berarti percaya pada diri sendiri, walaupun memiliki keterbatasan-keterbatasan dalam ilmu dan pengetahuan, namun individiu memiliki kekuatan dalam bidang-bidang tertentu lainnya, sehingga mampu menutupi keterbatasan tersebut. Untuk itu individu menjadi tetap merasa percaya diri.

Moore (1952) menjelaskan bahwa kepercayaan diri berarti persepsi percaya pada dirinya sendiri, pengetahuan terhadap suatu keterbatasan dan suatu kekuatan, kemampuan meyakini pada saat dihadapkan pada suatu situasi tertentu. Menurutnya, kepercayaan diri dapat menjadi trademark dari proses perkembangan kepribadian. Kepercayaan diri pula memiliki peran yang penting dalam menentukan individu layak atau tidaknya menjadi seorang pemimpin. Namun selain daripada itu, kepercayaan diri sangat dipengaruhi oleh gaya pengasuhan orangtua, yang mana dalam hal ini gaya pengasuhan demokratis menjadi salah satu dasar dari terbentukan kepercayaan diri dan berani melakukan kompetisi, karena hal ini bergantung kepada cara pandang individu terhadap dirinya dalam kehidupan seharihari.

Kepercayaan diri sebagai esensi kualitas, sebagaimana diungkapkan Moore (1952), merupakan penentu kemampuan sesorang dalam menggunakan pengetahuan, tanpa mempertimbangkan beberapa hal. Oleh karena itu, menurut Rini (2002), individu yang mempunyai kepercayaan diri akan menunjukkan indikasi sebagai berikut:

a. Percaya akan kompetisi atau kemampuan diri, sehingga tidak membutuhkan pujian, pengakuan ataupun rasa hormat orang lain.

b. Tidak terdorong untuk menunjukkan 
sikap konformitas demi diterima oleh orang lain atau kelompok

c. Berani menjadi diri sendiri

d. Punya pengendalian diri yang baik (emosinya stabil)

e. Memiliki internal locus of control memandang keberhasilan atau kegagalan, tergantung dari usaha sendiri dan tidak mudah menyerah pada nasib atau keadaan, serba tidak bergantung atau mengharapkan bantuan orang lain.

f. Mempunyai cara pandang yang positif terhadap diri sendiri, orang lain, dan situasi di luar dirinya

g. Memiliki harapan yang realistis terhaap diri sendiri, sehingga ketika harapan itu tidak terwujud dapat tetap mampu melihat sisi positif dirinya dan situasi yang terjadi.

Kepercayaan diri adalah keyakinan pada suatu keberhasilan yang dapat dicapai melalui berbagai pekerjaan dengan sikap yang optimis. Kepercayaan diri menunjukkan korelasi yang signifikan dengan kemampuan performan olahraga, namun demikian terdapat hubungan kausal. Bandura menggunakan istilah self efficacy untuk menggambarkan keyakinan diri sebagai salah satu perilaku dalam mencapai keberhasilan (contohnya pada performansi olahraga), yang mana perilaku ini menghasilkan suatu keluaran yang berkaitan dengan kepercayaan diri seseorang untuk mencapainya (Fletz, 1988).

Berdasarkan sumber diketahui dukungan sosial yang berpengaruh terhadap rasa percaya diri adalah hubungan dengan orang tua dan hubungan dengan teaman sebaya. Menurut Hakim (2002), secara garis besar terbentuknya rasa percaya diri yang kuat ada 4, yaitu:

a. Terbentuknya kepribadian yang baik sesuai dengan proses perkembangan yang melahirkan kelebihan-kelebihan tertentu.

b. Pemahaman seseorang terhadap kelebihan-kelebihan yang dimilikinya dan melahirkan keyakinan kuat untuk bias berbuat segala sesuatu dengan memanfaatkan kelebihan-kelebihannya.

c. Pemahaman dan reaksi positif seseorang terhadap kelemahan-kelemahan yang dimilikinya supaya tidak menimbulkan rasa rendah diri atau rasa sulit menyesuaikan diri.

d. Pengalaman di dalam menjalani berbagai aspek kehidupan dengan menggunakan segala kelebihan yang ada pada dirinya.

Dalam olahraga, kepercayaan diri merupakan salah satu faktor psikologi yang paling menentukan atlet dalam mencapai kemenangan. Velley (Fletz, 1988). Menjelaskan tentang kebutuhan untuk ikut dalam kompetisi agar memberikan penampilan yang terbaik, sebagai bentuk orientasi diri terhadap kemampuannya, dan sebuah kemenangan sebagai suatu konsep ego yang ingin di penuhi. Seorang atlet akan melakukan keduanya sekaligus, yaitu pangalaman meraih kemenangan dan keinginan menunjukkan kemampuan diri.

Perilaku individu tidak berdiri sendiri, selalu ada hal yang mendorongnya dan tertuju pada suatu tujuan yang ingin dicapainya. Tujuan dan faktor pendorong ini mungkin disadari oleh individu, sesuatu yang konkrit ataupun abstrak. Kekuatan yang menjadi pendorong kegiatan individu disebut motivasi, yang menunjukkan suatu kondisi dalam diri inidividu tersebut melakukan kegiatan mencapai sesuatu tujuan. Motivasi terbentuk oleh tenagatenaga yang bersumber dari dalam dan luar diri individu (Sukmadinata, 2005).

Menurut beberapa ahli motivasi merupakan kekuatan yang memberikan energi, menyokong dan perilaku yang dilakukan secara langsung untuk mencapai tujuan (Eggen \& Kauchak, 2007; Brophy, 2004; Pintrich \&Schunk, 2002) dan beberapa peneliti pun telah menemukan hubungan yang positif dan kuat antara motivasi dengan pencapaian atau prestasi.

Motivasi yang ada pada anak-anak dapat dilihat dari proses belajar dalam mencapai sesuatu dari sekolahnya. Teknologi pendukung, dasar pembelajaran dan pemenuhan kebutuhan. Motivasi menurut Eggan dan Khauchak (2007) serta menurut Pintrich dan Schunk (2002) dapat digambarkan dengan dua kategori:

1. Extrinsic Motivation, yaitu motivasi yang digunakan pada aktivitas dalam menyelesaikan sesuatu sampai selesai. Contohya; pelajar yang belajar dengan 
keras untuk tes yang akan dilakukan, karena individu yakin dengan belajar akan mendapatkan nilai yang tinggi dalam menyelesaikan tesnya tersebut.

2. Intrinsic Motivation, yaitu motivasi yang dipengaruhi oleh dari dalam diri individu dalam menyelesaikan pekerjaan untuk kepentingannya. Contohnya ketika individu ingin mengerti tentang pelajaran dan individu kemudian belajar karena dengan mengerti dengan pelajarannya akan menguntungkannya.

Atkinson dan Atkinson (1996) mengemukakan bahwa motivasi adalah faktor-faktor yang menguatkan perilaku dan memberikan arahannya. Chaplin (1997) juga mengemukakan motivasi adalah satu variabel penyelang (yang ikut campur tangan) yang digunakan untuk menimbulkan faktor-faktor tertentu di dalam organisme yang membangkitkan. Mengelola, mempertahankan, dan menyalurkan tingkah laku menuju satu tujuan.

Motivasi berprestasi atau pencapaian merupakan persepsi individu pada kemungkinannya terhadap suatu pencapaian satu tugas yang dirasakan membutuhkan suatu prestasi atau pencapaian dan ditakutkan gagal dalam mencapainya. Menurut Zenzen (2002), kedua hal tersebut merupakan emosi yang kuat dan dapat memberikan pengaruh yang besar bagi seorang individu dalam mengambil keputusan untuk menerima atau tidak bertanggung jawab terhadap hal tersebut.

Menurut Maslow, orang dewasa secara normal memuaskan dirinya kira 85\% kebutuhan fisiologis, 70\% kebutuhan rasa aman, 50\% kebutuhan untuk memiliki dan mencintai, 40\% kebutuhan harga diri serta $10 \%$ dari kebutuhan aktualisasi diri. Studi motivasi yang cukup terkenal dilakukan oleh David McClelland (1961) menjelaskan salah satu nya adalah Need for Achievment, yaitu kebutuhan untuk berprestasi sebagai refleksi dari dorongan akan tanggung jawab untuk memecahkan masalah. Seseorang yang memiliki kebutuhan berprestasi tinggi cenderung untuk bertindak dan mengambil keputusan dengan penuh resiko. Kebutuhan berprestasi merupakan dorongan untuk melakukan tindakan atau pekerjaan lebih baik daripada sebelumnya dan selalu berkeinginan mencapai prestasi yang lebih tinggi.

Kebutuhan akan pencapaian sangat dipengaruhi oleh keinginan untuk berusaha mencapai kesuksesan. Haasen dan Shea (Zenzen, 2002) bahwa ketika seseorang tumbuh motivasidalam dirinya, hal ini mengimplikasikan suatu potensi kekuatan dalam dirinya untuk melakukan suatu aktualisasi diri. Potensi ini didasari oleh intensitas kebutuhan untuk mencapai sesuatu. Seseorang yang memiliki intrinsik motivasi dengan belajar dan latihan, dalam mencapai tujuannya, selain itu mereka tidak membutuhkan penghargaan dan hadiah, merasa puas mengetahui bahwa apa yang dilakukan saat ini (belajar dan latihan) akan memberikan benefit di masa depannya.

Berdasarkan para ahi diatas dapat disimpulkan bahwa seorang individu yang memiliki motivasi berprestasi tinggi akan memperoleh sebuah kemenangan pada apa yang telah menjadi tujuannya, selain itu McClelland menambahkan beberapa faktor yang sangat mempengaruhi motivasi dan pencapaian prestasi, yaitu tingkat kecerdasan (IQ) dan kepribadian. Orang yang memiliki motivasi berprestasi tinggi, jika memiliki kecerdasan yang memadai dan ditunjang oleh kepribadian yang matang akan mampu mencapai prestasi yang maksimal. Hal ini dapat dijelaskan bahwa IQ merupakan potensi yang dimiliki seseorang dan kepribadian merupakan kemampuan untuk mengintegrasikan fungsi psikofisik yang sangat menentukan dirinya dalam menyesuaikan diri terhadap lingkungan.

\section{Simpulan}

\section{PENUTUP}

Berdasarkan hasil penelitian yang telah dilakukan ini, dapat disimpulkan bahwa terdapat hubungan positif yang sangat signifikan antara Motivasi berprestasi dengan Kepercayaan diri atlet dalam menghadapi PON ke-18 tahun 2012. Selain itu hasil penelitian ini menunjukkan bahwa motivasi berprestasi atlet dalam menghadapi PON ke-18 tahun 2012 termasuk dalam kategori Rendah, dan Kepercayaan diri menunjukkan kategori Sangat Rendah. 


\section{Saran}

Dengan demikian perlu dilakukan suatu upaya untuk meningkatkan kepercayaan diri atlet agar dapat lebih memiliki motivasi dalam mencapai prestasi diajang olahraga terbesar di Indonesia, yang dilaksanakan di Provinsi Riau pada tahun 2012.

Disarankan kepada peneliti selanjutnya untuk memperhatikan faktorfaktor lain sebagai pendukung dalam meningkatkan Motivasi Berprestasi, seperti, kommunikasi interpersonal pelatih dengan atlet, dan sebagainya.

\section{DAFTAR PUSTAKA}

Ancok, D. \& Suroso. (2008). Psikologi Islami: Solusi Islam atas Problemproblem Psikologi. Yogyakarta: Pustaka Pelajar.

Atkinson, R \& Atkinson. R.L. (1996). Pengantar Psikologi. Jakarta: PT. Erlangga

Azwar, S. (1999). Penyusunan Skala Psikologi. Yogyakarta: Pustaka Pelajar

Chaplin, J.P. (1996). Kamus Pengantar Psikologi. Jakarta: Raja Grafindo.

Eggen, P \& Kauchak, D. (2007). Educational Psychology; Windows on Classrooms. Pearson International Edition.

Feltz, D. \& Lirgg, C.D. (2001). Self Efficacy; Belief of Athletes, Teams and Coach. Michigan: State University and University of Arkansas
Feltz, D. L. (1988). Self-Confidence and Sport Performance. Michigan State University

Hadi, S. (2000). Statistik. Yogyakarta: Andi Offset.

Moore, B.M. (1952). Self-Confidence for competence. Educational Leadership

Pasiak, T. (2004). Membangunkan raksasa tidur: Otimalkan kemampuan otak anda dengan metode ALISSA. JAKARTA : P T. Gramedia Pustaka Utama.

Siddik, D. Z. (2006). Panduan pelatihan olahraga untuk usia sekolah. http://www.koni.or.id/files/documen ts/journal/1.Panduan-PelatihanOlahraga-Untuk-Usia-Sekolah-(618Tahun).pdf), diakses tanggal 10 Januari 2009

Sukmadinata, N. S. (2005). Landasan Psikologi Proses Pendidikan. Bandung; PT. Rosdakarya.

Uyun, Q. (1998). Religiusitas dan Motif Berprestasi Mahasiswa. Jurnal Psikologika 3, (6), 45-54.

Thomas, E \& Kring, J. (1996). Anxiety and self-confidence in relation to individual and team sports and reevaluation. Emporia state University.

Zenzen, T.G. (2002). Achievement Motivation. A Research Paper. Wisconsin-Stout 